\author{
Research Article \\ www.ijrap.net (ISSN:2229-3566)
}

\title{
ASSESSMENT OF ANTIMICROBIAL ACTIVITY OF ETHANOLIC EXTRACTION OF USNEA GHATTENSIS AND USNEA UNDULATA
}

Archana Ramachandra Mesta ${ }^{1 *}$, Rajeswari $\mathrm{N}^{2}$ and Vinayaka Shankarnarayana Kanivebagilu ${ }^{3}$

${ }^{1}$ Research Scholar, Department of Botany, Kumadvathi First Grade College, Shimoga Road, Shikaripura, Shimoga, Karnataka, India

${ }^{2}$ Associate Professor, Department of Botany, Sahyadari Science College, Shimoga, Karnataka, India

${ }^{3}$ Associate Professor, Department of Botany, Kumadvathi First Grade College, Shimoga Road, Shikaripura, Shimoga, Karnataka, India

Received on: 18/09/19 Accepted on: 04/11/19

\author{
*Corresponding author \\ E-mail: archu.mesta@gmail.com
}

DOI: $10.7897 / 2277-4343.110115$

\begin{abstract}
The fungal partner of lichens produces a great variety of biologically active metabolites such as antibiotic, antiviral, anti-inflammatory and many others. Antimicrobial is a substance which either inhibits the growth of micro-organism or kills the microbes. The pathogenic microorganisms causing number of diseases in plants and animals have developed resistance against many commonly available chemicals and antibiotics. Lichens are the combination of two life forms algae and fungi. A large number of lichens are known for the source of important secondary metabolites. The present study aims at the antimicrobial properties of two species of Usnea belonging to the largest family Parmeliaceae. The antibacterial activity of two species of Usnea was tested against six organisms such as Staphylococcus aureus, Streptococcus pneumoniaee, Salmonella typhi, Escherichia coli, Vibrio choleraee, Bacillus coagulans. Both species of Usnea had shown inhibitory activity against all pathogen but to different extent. These two species of Usnea are found in large quantity in Mullayangiri of Karnataka and these two species can be used sustainably in the preparation of antimicrobials.
\end{abstract}

Keywords: Usnea, antimicrobial, pathogen, Parmeliaceae

\section{INTRODUCTION}

The symbiotic association of fungi and algae or cyanobacteria forms the slow growing life forms called lichens. Lichens are very sensitive organisms and show poor growth in industrial area and big cities. Hence they are considered as indicators of air pollution ${ }^{1}$. More than $50 \%$ of lichens that have been studied synthesize substances with some degree of antimicrobial activity $^{2}$. Many researches have been carried out to prove the antifungal and antimicrobial activity of the lichens. Different concentrations of lichen extracts have a variable degree of lichen activity $^{3}$. Antifungal and antimicrobial activity of extracts from Usnea species is extremely proved. Secondary metabolites such as Usnic acid, Pulvinic acid derivatives, aliphatic acids, orcinol type depsides and depsidones are well known for its effective antimicrobial activity.

Lichens and their products are used in traditional medicines for centuries and used as an alternative treatment in various parts of the world. The secondary metabolites of lichens are unique with respect to higher plants and are found their uses in many fields such as medicines, dyes, cosmetics, deodorants, preservatives and also in biopesticides. These lichens grow slowly but still they are resistant to decaying microorganisms. This fact suggests that the lichen substances are very effective antibiotics ${ }^{4}$.

The secondary metabolites from the lichens have the capacity to inhibit the seed germination in vascular plants and spore germination in mosses ${ }^{4}$. These antimicrobial roles of the secondary metabolites of lichens have made possible for the lichens to live for hundreds of years ${ }^{4}$. Usnea ghattensis and Usnea undulate are fruticose lichens with bushy thallus. U. ghattensis is erected bushy but $U$. undulate shows sub-pendant thallus. $U$. ghattensis is found growing in Karnataka and Maharashtra ${ }^{5,6}$ whereas U. undulata is distributed in states of Arunachal Pradesh, Meghalaya, Nagaland, Karnataka, Kerala and Tamil $\mathrm{Nadu}^{6,7}$.

\section{MATERIAL AND METHODS}

\section{Collection of the sample}

Lichen Usnea ghattensis is collected from the Mullayangiri and Kemmangundi hills of Karnataka and Mahabaleshwar hills of Maharashtra. The lichen $U$. undulate was collected from Mullayangiri peaks of Karnataka, India. The collected lichens were dried and stored in lichen herbarium of K.F.G.C. Shikaripura. The lichens were identified up to species, based on its anatomy, morphology and chemical characters ${ }^{8-12}$. The herbarium voucher specimen number of $U$. ghattensis is LHKFGC0012 and U. undulata is LHKFGC0015, are used for preparing the lichen extracts.

\section{Test organisms}

Six bacterial cultures were procured from Microbiology Department, Sahyadri Science College, Shimoga, India. Staphylococcus aureus, Streptococcus pneumoniae, Salmonella typhi, Escherichia coli, Vibrio cholerae, Bacillus coagulansare the 6 test organisms.

The lichens were washed, dried and ground to powder. $10 \mathrm{~g}$ portion of powder was added to $100 \mathrm{ml}$ of ethanol, mixed well, sonicated and left for 48 hours at room temperature with occasional stirring. The extracts were prepared by decanting the contents of flask through a clean muslin cloth and again with Whatman No.1 filter paper to get a clean filtrate. The filtrate was 
evaporated in oven at $40^{\circ} \mathrm{C}$ to get dried and concentrated extract. Thus obtained sterilized filtrate was stored in refrigerator ${ }^{13}$.

\section{Antibacterial Activity}

The bacterial activity of lichen extracts was evaluated by standard agar well diffusion method. $0.1 \mathrm{ml}$ of bacterial culture of 24 hours was evenly spread on sterile Mueller-Hinton agar plates with the help of sterile cotton swabs. The seeded plates were allowed to dry. The alcohol sterilized cork borer of $6 \mathrm{~mm}$ was used to made wells in plates. $100 \mu \mathrm{l}$ of different concentration $(10 \mathrm{mg} / \mathrm{ml}, 15$ $\mathrm{mg} / \mathrm{ml}$, and $25 \mathrm{mg} / \mathrm{ml}$ ) of lichen extract was loaded to the well. $10 \mu \mathrm{g} / \mathrm{ml}$ of tetracycline was taken as positive control and $10 \%$ DMSO was taken as negative control. Further the plates were kept for incubation at $37^{\circ} \mathrm{C}$ for 24 hours. After incubation the plates were observed for zone of inhibition and results were recorded. All the experiments were repeated and the data presented is the average of 3 replications.

Table 1: Zone of inhibition of ethanolic extracts of two Lichen species

\begin{tabular}{|c|c|c|c|c|c|c|c|}
\hline \multirow[t]{2}{*}{ Test Sample } & \multirow{2}{*}{$\begin{array}{l}\text { Concentration of } \\
\text { Test sample }\end{array}$} & \multicolumn{6}{|c|}{ Zone of inhibition in $\mathrm{mm}$} \\
\hline & & $\begin{array}{c}\text { Staphylococcus } \\
\text { aureus }\end{array}$ & $\begin{array}{l}\text { Streptococcus } \\
\text { pneumoniae }\end{array}$ & $\begin{array}{c}\text { Salmonella } \\
\text { typhi }\end{array}$ & $\begin{array}{c}\text { Escherichia } \\
\text { coli }\end{array}$ & $\begin{array}{c}\text { Vibrio } \\
\text { cholerae }\end{array}$ & $\begin{array}{c}\text { Bacillus } \\
\text { coagulans }\end{array}$ \\
\hline \multirow[t]{3}{*}{ Usnea ghattensis } & $10 \mathrm{mg} / \mathrm{ml}$ & 10 & 11 & 12 & 13 & 13 & 13 \\
\hline & $15 \mathrm{mg} / \mathrm{ml}$ & 12 & 12 & 14 & 15 & 15 & 14 \\
\hline & $25 \mathrm{mg} / \mathrm{ml}$ & 16 & 17 & 18 & 17 & 18 & 16 \\
\hline \multirow[t]{3}{*}{ Usnea undulata } & $10 \mathrm{mg} / \mathrm{ml}$ & 14 & 16 & 12 & 15 & 14 & 14 \\
\hline & $15 \mathrm{mg} / \mathrm{ml}$ & 16 & 18 & 16 & 17 & 17 & 17 \\
\hline & $25 \mathrm{mg} / \mathrm{ml}$ & 20 & 20 & 19 & 20 & 20 & 20 \\
\hline Tetracycline & $10 \mathrm{mg} / \mathrm{ml}$ & 26 & 24 & 26 & 26 & 26 & 26 \\
\hline
\end{tabular}

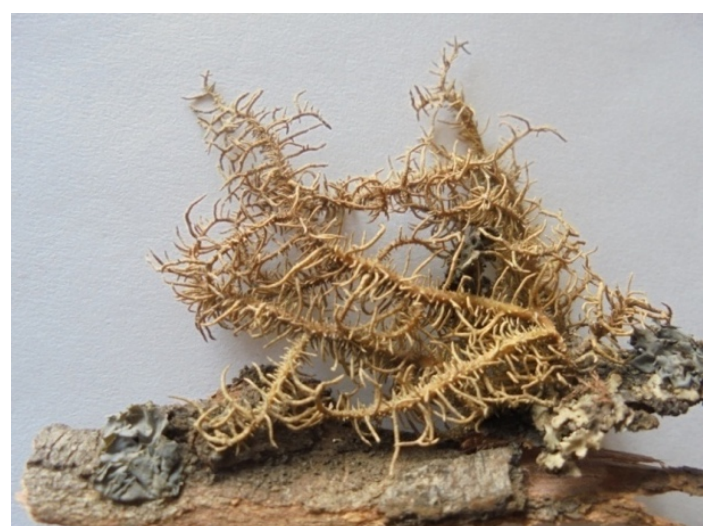

Usnea ghattensis

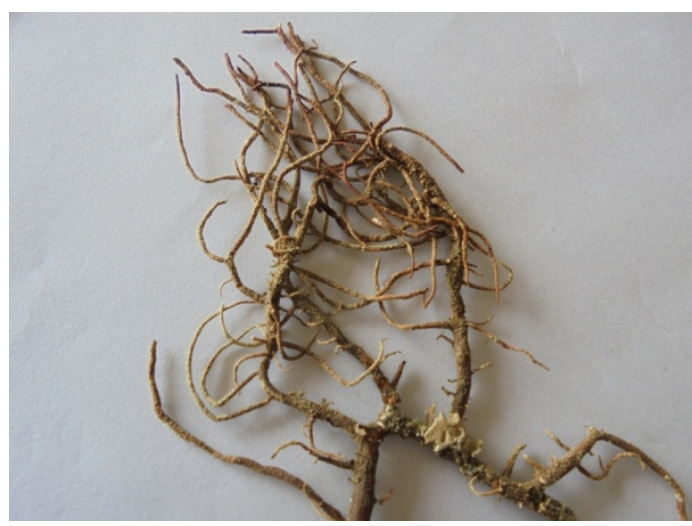

Usnea undulata

\section{RESULT AND DISCUSSION}

The result of inhibitory activity of extracts of Usnea ghattensis and $U$. undulate were observed on the growth of various microorganisms such as Staphylococcus aureus, Streptococcus pneumoniae, Salmonella typhi, Escherichia coli, Vibrio cholerae, Bacillus coagulans. Lichen extracts of both species had shown inhibitory activity against all pathogen but to different extent (Table 1).

U. ghattensis shows maximum zone of inhibition against 3 microorganisms that is, Escherichia coli, Vibrio cholera and Bacillus coagulans of $13 \mathrm{~mm}$.

$U$. undulate shows maximum zone of inhibition against Streptococcus pneumonia with $16 \mathrm{~mm}$ of zone followed by Escherichia coli with $15 \mathrm{~mm}$. The more concentrated test samples shows the more zone of inhibition. At lower concentration of 10 $\mathrm{mg} / \mathrm{ml} U$. ghattensis shows minimum inhibition for Streptococcus aureus and Salmonella typhi and U. undulata shows for Salmonella typhi with $10 \mathrm{~mm}$ and $16 \mathrm{~mm}$ respectively. The results of present study was compared with the findings of ${ }^{13,14}$ who worked on the inhibitory activity of ethanolic extracts of $U$. longissima and $U$. barbata against gram positive and gram negative bacteria and found in accordance with their results.

\section{CONCLUSION}

Usnea produces a number of secondary metabolites. The ethanolic extracts of $U$. Ghattensis and $U$. undulate have high antibacterial potential. These two species of lichens are found in more number in Karnataka. The unscientific methods of gathering lichens may have negative impact on the ecology. Hence sustainable harvesting of lichens may result in the preparation of a potential antibacterial drug.

\section{ACKNOWLEDGEMENT}

The authors are thankful to the DST-SERB for financial support throughout the work. We are thankful to Swamy Vivekananda Vidya Samsthe, Shikaripura, Shimogaand Sahyadari Science College (A), Shimoga for providing platform for conducting the current research work.

\section{REFERENCES}

1. Jezierski A, Bylinska E and Seaward MRD. Electron paramagnetic resonance investigation of lichen and effects of air pollution. Atm Environ 1999; 3: 4629-4635.

2. Dayan FE and Romagni JG. Lichens as a potential source of pesticides. Pestic Outlook 2001; 6: 229-232.

3. Prasad CM and Kunwar IK. Effect of lichen extracts on the growth of fungi. Indian Bot. Soc 1994; 73: 353-354. 
4. Lawrey JD. Biological role of lichen substances. The Bryologist 1986; 89: 111-122.

5. Upreti DK, Tiwari P, Shukla P, Dwivedi A. Natural thalli and cultured mycobiont of Usnea ghattensis G. Awasthi-A potential source of purple dye yielding lichen from India. Ind J Natural products Resources 2012; 3(4): 489-492.

6. Mesta AR, Vinayaka KS, Rajeswari N. Distribution Pattern and ecology of Usneoid lichens in Western Ghats, Southern India. J New Biological Reports 2015; 4(3): 247-254.

7. Shukla P, Upreti DK, Tewari LM. Lichen genus Usnea (Parmeliaceae, Ascomycota) in Uttarakhand, India. Curr Res Environ Appl. Mycol 2014; 4(2): 188-201.

8. Awasthi DD. In: A Compendium of the Macro lichens from India, Nepal and Sri Lanka. Bishen Singh Mahendra Pal Singh Publishers and Distributors of Scientific Books, Dehra Dun, India; 2000. p. 1-580.

9. Nayaka S and Upreti DK. Lichen flora of Sharavathi River Basin, Shimoga district, Karnataka, India, with six new records. J. Econ. Taxo. Bot 2002; 26(3): 627-648.
10. Walker FJ and James PW. A revised guide to microchemical techniques for the identification of lichen substances. Bull. British Lichenol. Soc 1980; 46: 13-29.

11. Awasthi DD. A key to macro lichens of India and Nepal. J. Hattori Bot. Lab 1988; 65: 207-302.

12. Awasthi DD. In: A Hand Book of Lichens. Bishen Singh Mahendra Pal Singh. Dehra Dun; 1999. p. 1-125.

13. Tippeswamy B, Naveenkumar KJ, Guruprasad Bodharthi J and Shivaprasad SR. Antimicrobial activity of ethanolic extract of Usnea longissima. J. Clin Patho 2011; 2: 01-03.

14. Srivastava P, Upreti DK, Dhole TN, Srivastava AK, Nayak MT. Antimicrobial property of extracts of Indian lichen against human pathogenic bacteria. Interdisciplinary perspectives on Infectious Diseases 2013; 2013: 6 .

\section{Cite this article as:}

Archana Ramachandra Mesta et al. Assessment of antimicrobial activity of ethanolic extraction of Usnea ghattensis and Usnea undulata. Int. J. Res. Ayurveda Pharm. 2020;11(1):75-77 http://dx.doi.org/10.7897/2277-4343.110115

\section{Source of support: DST-SERB, Conflict of interest: None Declared}

Disclaimer: IJRAP is solely owned by Moksha Publishing House - A non-profit publishing house, dedicated to publish quality research, while every effort has been taken to verify the accuracy of the content published in our Journal. IJRAP cannot accept any responsibility or liability for the site content and articles published. The views expressed in articles by our contributing authors are not necessarily those of IJRAP editor or editorial board members. 